\title{
Edge-interior differences in the species richness and abundance of drosophilids in a semideciduous forest fragment
}

\author{
Leiza V Penariol and Lilian Madi-Ravazzi
}

\begin{abstract}
Habitat fragmentation is the main cause of biodiversity loss, as remnant fragments are exposed to negative influences that include edge effects, prevention of migration, declines in effective population sizes, loss of genetic variability and invasion of exotic species. The Drosophilidae (Diptera), especially species of the genus Drosophila, which are highly sensitive to environmental variation, have been used as bioindicators. A twelve-month field study was conducted to evaluate the abundance and richness of drosophilids in an edge-interior transect in a fragment of semideciduous forest in São Paulo State, Brazil. One objective of the study was to evaluate the applied methodology with respect to its potential use in future studies addressing the monitoring and conservation of threatened areas. The species abundance along the transect showed a clear gradient, with species associated with disturbed environments, such as Drosophila simulans, Scaptodrosophila latifasciaeformis and Zaprionus indianus, being collected at the fragment edge and the species D. willistoni and D. mediostriata being found in the fragment's interior. Replacement of these species occurred at approximately 60 meters from the edge, which may be a reflection of edge effects on species abundance and richness because the species found within the habitat fragment are more sensitive to variations in temperature and humidity than those sampled near the edge. The results support the use of this methodology in studies on environmental impacts.
\end{abstract}

Keywords: Forest fragmentation, Drosophilid biodiversity, Bioindicator species, Edge effects

\section{Introduction}

Fragmentation is a threat to global biodiversity. The fragmentation process affects biodiversity by reducing habitat availability and altering the habitat properties of the remaining fragments (Laurence et al., 2007). Following fragmentation, the primary negative impacts in habitat remnants are edge effects, reduced migration rates, declines in effective population sizes, loss of genetic variability and invasion of exotic species (Fahring, 2003). There are three types of edge effects that influence habitat fragments: (1) abiotic effects, which result from the proximity to a structurally dissimilar matrix and involve changes in environmental conditions; (2) direct biological effects, which involve changes in the abundance and distribution of species, either as a direct result of altered physical

\footnotetext{
* Correspondence: lilian@ibilce.unesp.br

Departamento de Biologia, Instituto de Biociências, Letras e Ciências Exatas de São José do Rio Preto/UNESP-IBILCE, Rua Cristovão Colombo, 2265, CEP
} 15054-000, São Paulo, Brazil conditions or indirectly, as mediated through the physiological tolerances of species to conditions at and near the edge (for example, higher light levels, wind exposure, temperatures and humidity); and (3) indirect biological effects, which involve changes in species interactions, such as predation, brood parasitism, competition and herbivory, biotic pollination and seed dispersal (Murcia, 1995).

According to the Biological Dynamics of Forest Fragments Project (BDFFP), which has evaluated the impacts of fragmentation on the Amazon rainforest and its biota, edge effects are among the most important drivers of ecological change in habitat fragments (Laurance et al., 2011). Today, 32 years after its initiation, BDFFP is the world's largest and longest-running experimental study of habitat fragmentation as well as one of the most highly cited ecological investigations ever conducted (Gardner et al. 2009; Peres et al. 2010).

Edge size is an important factor in evaluating the environmental impacts within a fragment. Data from the

\section{实}


relevant literature indicate that the extent of the edge ranges from 50 to 500 meters (Laurence, 2000), but current consensus holds that edge effects typically extend 150 meters into a fragment (Bierregaard et al., 1992; Murcia, 1995).

Fragmentation stands out among the ecological challenges that affect protected areas. Knowledge regarding the factors that influence diversity in habitat fragments and their effects on native populations can indicate appropriate strategies and control mechanisms for the management of these areas.

Species of the genus Drosophila are used in many areas of biological inquiry as model organisms. These flies are potential candidates for monitoring the degree of environmental disturbance in a given area (Parsons, 1991), as permanent changes in the Drosophila fauna imply significant biotic changes in the plant, fungus and parasitic wasp species that are associated with different stages of the Drosophila life cycle (Prince 1976; Chabora et al. 1979). Changes in temperature and humidity are known to affect vital parameters in Drosophila species, including their survival, fertility, development time and other factors that influence population growth rates and viability (Sene et al. 1980; Tidon-Sklorz and Sene 1992; Balanya et al. 2006; Torres and Madi-Ravazzi 2006).

The potential for these flies to serve as environmental indicators is demonstrated by the cosmopolitan character of the group, the sensitivity of the flies to environmental variables and the simplicity of collecting them (Parsons 1991; Foote and Carson 2004).

The drosophilids include many exotic species, comprising a number of species with a long history of invasion. These flies are primarily found in environments disturbed by man, in open areas, or in degraded and urbanized environments which are characterized by a pronounced degree of environmental stress; D. simulans, D. malerkotliana, D. melanogaster, Scaptodrosophila latifasciaeformis and Zaprionus indianus occupy such environments. However, some native neotropical species, such as $D$. willistoni, occur only in forested areas and protected environments. These species may therefore be used as bioindicators of environmental conditions (Saavedra et al. 1995; Amaral 2004; Ferreira and Tidon 2005; Torres and Madi-Ravazzi 2006; Penariol 2007; De Toni et al. 2007; Schmitz et al. 2007; Gottschalk et al. 2007; Mata et al. 2008, Acurio et al. 2010).

The effects of habitat fragmentation have been studied in numerous taxa, including plants (Bierregaard et al. 1992; Laurance et al. 1998; Oliveira-Filho et al. 2004), birds (Kroodsma, 1984), and invertebrates (Mcgeoch and Gaston 2000; Demite and Feres 2005; Oliveira-Alves et al. 2005). However, few studies (Martins 1989; Amaral 2004; Penariol 2007) have evaluated the effects of edges on the drosophilid fauna, which therefore represents a relatively novel approach.
The semideciduous forest ecosystem within the Atlantic Forest extends along the central and southeast regions of Brazil's interior. This vegetation type has experienced severe devastation. In the northwestern region of São Paulo, it is now limited to $9 \%$ of its original area. Few investigations have focused on understanding and protecting the species biodiversity associated with the semideciduous forest (SMA/IF 2005; Kronka et al. 1993) To contribute to the knowledge of the fauna of this region and to establish conservation and monitoring strategies for Atlantic Forest fragments, this study evaluated ecological parameters of Drosophilidae as well as the use of these organisms in studies addressing size and edge effects in one of the last remaining fragments of semideciduous forest in São Paulo State, Brazil.

\section{Materials and methods}

\section{Study area and collection methods}

Flies were collected at the Ecological Station of Paulo de Faria $\left(19^{\circ} 55^{\prime}\right.$ to $19^{\circ} 58^{\prime} \mathrm{S}$ and $49^{\circ} 31^{\prime}$ to $\left.49^{\circ} 32^{\prime} \mathrm{W}\right)$ in São Paulo State, Brazil, which is a 435-hectare fragment of seasonal, semideciduous forest (Figure 1). The historic vegetation of this region was a mesophytic semideciduous forest, which was altered for use as pastures and for various monocultures; during the sample period, these crops included corn and cane sugar. This region is characterized by a well-pronounced dry season that accounts for less than 15\% of annual precipitation (Barcha and Arid, 1971 and unpredictable rainfall at the beginning of the rainy season (Rossa-Feres and Jim, 2001). The average annual temperature and precipitation are $27^{\circ} \mathrm{C}$ and $127.67 \mathrm{~mm}$, respectively.

Collections were performed monthly, from September 2004 to August 2005, along a 200-meter transect (Figure 2) extending from the edge toward the interior of the fragment. Eleven collection points were distributed along the transect at 20-meter intervals (at 0, 20, 40, 60, 80, 100, $120,140,160,180$ and 200 meters). To catch flies, closed traps (Penariol et al., 2008) were placed approximately $1.5 \mathrm{~m}$ above the soil surface. The traps contained bait prepared with macerated banana and biological yeast (Saccharomyces cerevisiae) and were left at the collection sites for a period of three days.

The flies captured in the closed traps were transferred directly to glass tubes. Subsequently, the specimens were transferred to bottles containing standard culture medium and transported to a laboratory. Specimens were identified according to a standard process using identification keys and, when necessary, by examining the aedeagus (Freire-Maia and Pavan 1949; Kaneshiro 1969; Vilela 1983).

\section{Statistical analysis}

The efficiency of the sampling methodology was evaluated using richness accumulation curves and via richness 


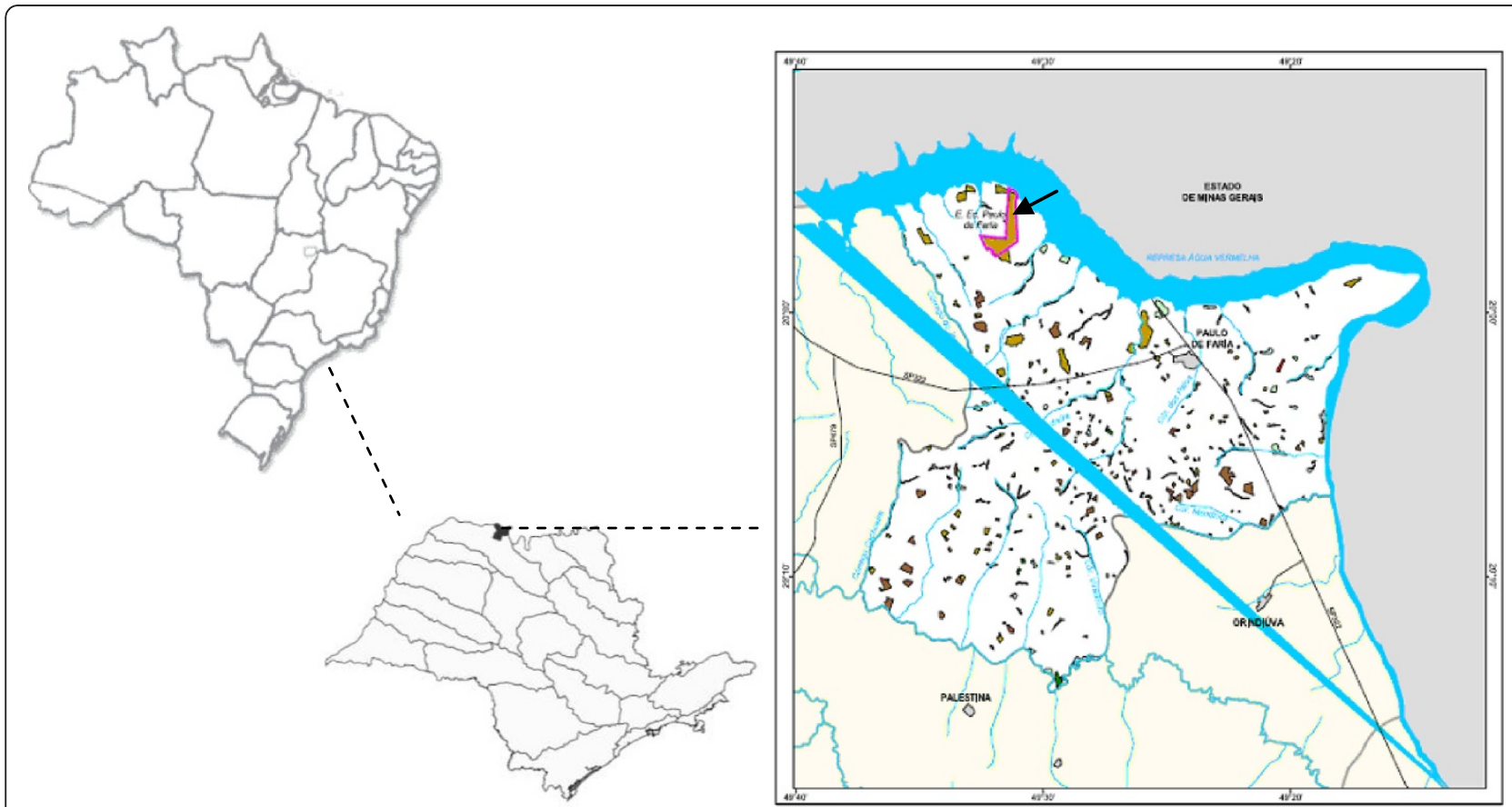

Figure 1 Geographic location of Paulo de Faria, in northern region of the state of São Paulo-Brazil and location of Estação Ecológica de Paulo de Faria.

estimates obtained with the Abundance Coverage Estimator (ACE) and Incidence Coverage Estimator (ICE) provided in the Estimate Swin 7.0 program (Colwell, 2004).Species abundance and richness were analyzed descriptively from graphics prepared in Microsoft Excel 7.0 for Windows. Comparisons between the species distribution and distance along the transect were performed via Analysis of Dependence (Anadep, Cordeiro, 1987).

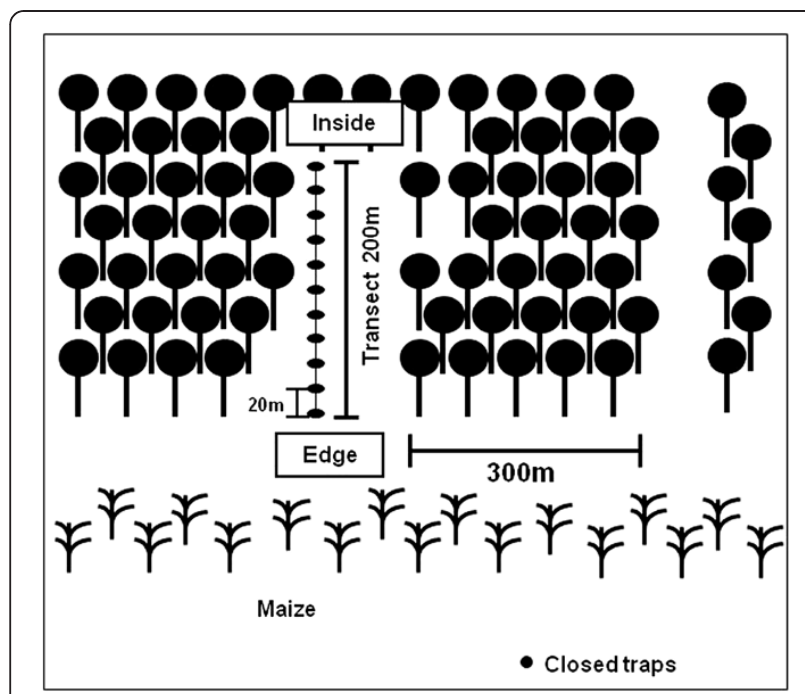

Figure 2 Drawing the sample used for collection in the fragment.

\section{Results and discussion}

A total of 6,832 drosophilids distributed among 17 species were captured along the transect, and curves to estimate richness were calculated using the ACE and ICE methods. Both richness estimators exhibited a trend toward stabilization, which demonstrates efficient sampling (Figure 3). Four distinct patterns of species abundance emerged (Table 1). The abundance of the species D. simulans, D. malerkotliana and Z. indianus was high at sampling points near the edge and decreased toward the interior of the fragment. The opposite pattern was

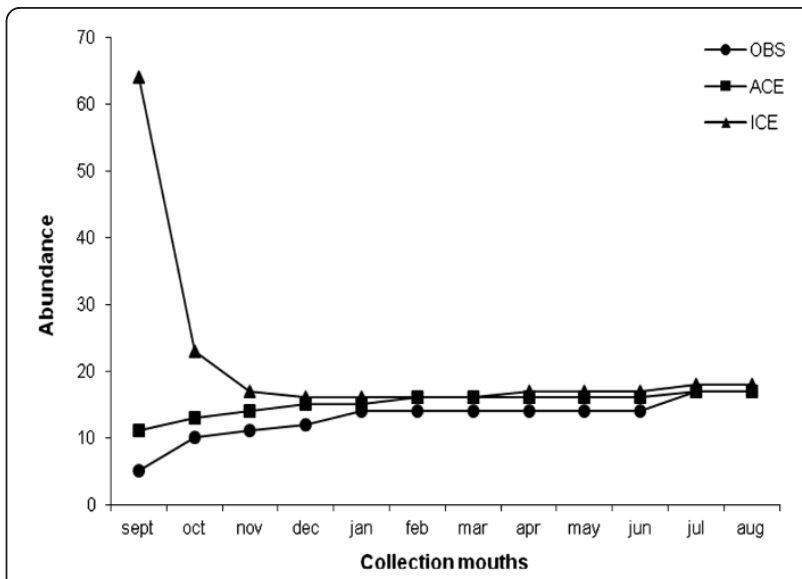

Figure 3 Curves of accumulation of richness estimated by methods ACE and ICE compared with the richness observed (OBS). 
observed for $D$. willistoni, which exhibited a high abundance within the fragment and became less common toward the edge. The species S. latifasciaeformis was observed only at the fragment edge (up to 60 meters from the edge), while $D$. mediostriata was collected only within the fragment (inward of 120 meters). Other species exhibited no patterns in their abundance related to the distance from the fragment edge.

Drosophila simulans was the dominant species up to 60 meters along the transect, with $63 \%$ of its total abundance being recorded within this edge region. $D$. willistoni dominated the collections beyond 80 meters, where $86 \%$ of its total abundance was found. Z. indianus was the second most abundant species in the edge region up to 20 meters, with $63 \%$ of its total abundance being concentrated here, and this species occurred up to 80 meters from the fragment edge. The species $D$. sturtevanti, which was one of the most abundant species, was collected along the entire length of the transect (Figure 4).

The Anadep data, shown in Figure 5, indicate an association between the distance from the edge and species richness. According to this analysis, the species abundance data along the transect formed two groups, the first of which extended from 0 to 60 meters (edge region) and the other from 80 to 200 meters (interior region). The species S. latifasciaeformis, Z. indianus, D. malerkotliana and $D$. simulans were more closely associated with the edge of the fragment, while D. mediostriata, D. immigrans,
D. austrosaltans, D. willistoni and D. ornatifrons were associated with the fragment's interior. The statistical analysis confirmed the descriptive trends obtained from charts, which suggested a higher abundance of invasive species in the edge region (up to 60 meters) and of neotropical species in the interior (beyond 60 meters from the edge).

These results indicate that the effects of the edge on the drosophilid assemblage in this fragment extended to 60 meters. The edge-interior transition was demonstrated by a shift from dominance of $D$. simulans to dominance of D. willistoni. Scientific consensus maintains that these effects can extend up to 500 meters from the edge, but an edge-effect distance of 100 meters has been found to be typical for diverse flora and fauna (Laurence, 2000).

In this study, the edge favored the dominance of invasive species, such as Z. indianus and D. simulans, and limited the occurrence of native species, such as D. willistoni. In a study conducted in different areas of the Cerrado, (Mata et al. 2008) observed that neotropical drosophilid species were more abundant in undisturbed forests, while exotic and generalist species were dominant in disturbed forests, grasslands and urban areas. These authors identified five species as indicators of undisturbed forest: D. willistoni, D.ornatifrons, D. mediopunctata, D. maculifrons and D. paraguayensis. Of these species, D. willistoni, D. ornatifrons, D. mediopunctata were also collected in the present study, in the fragment interior.

Table 1 Abundance of drosophilid species collected at each point of transect across the period of collection

\begin{tabular}{|c|c|c|c|c|c|c|c|c|c|c|c|c|c|}
\hline \multirow[t]{2}{*}{ Group } & \multirow[t]{2}{*}{ Species } & \multicolumn{11}{|c|}{ Edge distance in meters } & \multirow[t]{2}{*}{ Total } \\
\hline & & 0 & 20 & 40 & 60 & 80 & 100 & 120 & 140 & 160 & 180 & 200 & \\
\hline \multirow[t]{2}{*}{ melanogaster } & D. simulans & 503 & 317 & 228 & 232 & 145 & 139 & 109 & 137 & 84 & 56 & 69 & 2.019 \\
\hline & D. malerkotliana & 33 & 24 & 31 & 20 & 6 & 9 & 4 & 0 & 3 & 0 & 2 & 132 \\
\hline \multirow[t]{2}{*}{ willistoni } & D. willistoni & 43 & 41 & 76 & 127 & 213 & 233 & 224 & 304 & 291 & 225 & 320 & 2.097 \\
\hline & D. nebulosa & 28 & 11 & 8 & 12 & 11 & 11 & 7 & 11 & 9 & 19 & 16 & 143 \\
\hline cardini & D. polymorpha & 48 & 29 & 36 & 26 & 37 & 8 & 12 & 26 & 39 & 26 & 29 & 316 \\
\hline guarani & D. ornatifrons & 0 & 7 & 12 & 1 & 7 & 3 & 5 & 7 & 10 & 7 & 15 & 74 \\
\hline \multirow[t]{2}{*}{ tripunctata } & D. mediopunctata & 0 & 7 & 29 & 0 & 0 & 0 & 1 & 9 & 4 & 2 & 3 & 55 \\
\hline & D. mediostriata & 0 & 0 & 0 & 0 & 0 & 0 & 3 & 3 & 1 & & 2 & 9 \\
\hline annulimana & D. ararama & 7 & 4 & 2 & 5 & 0 & 4 & 3 & 2 & 6 & 3 & 8 & 44 \\
\hline immigrans & D. immigrans & 0 & 0 & 0 & 1 & 0 & 1 & 0 & 0 & 0 & 1 & 2 & 5 \\
\hline \multirow[t]{3}{*}{ saltans } & D. sturtevanti & 74 & 67 & 57 & 74 & 70 & 78 & 67 & 105 & 84 & 89 & 101 & 866 \\
\hline & D. prosaltans & 8 & 5 & 7 & 9 & 7 & 1 & 9 & 7 & 20 & 15 & 8 & 96 \\
\hline & D. austrosaltans & & & 3 & 1 & 11 & 4 & 7 & 6 & 6 & 3 & 5 & 46 \\
\hline \multirow[t]{2}{*}{ repleta } & D. mercatorum & 27 & 32 & 34 & 19 & 22 & 24 & 25 & 22 & 29 & 14 & 20 & 268 \\
\hline & D. paranaensis & 21 & 50 & 38 & 19 & 17 & 14 & 16 & 18 & 12 & 19 & 27 & 251 \\
\hline \multirow[t]{2}{*}{ Others drosophilids } & Z. indianus & 135 & 91 & 60 & 37 & 25 & 2 & 7 & & 1 & 1 & & 359 \\
\hline & S. latifasciaeformis & 30 & 10 & 9 & 3 & & & & & & & & 52 \\
\hline Species richness & & 12 & 14 & 15 & 15 & 12 & 14 & 15 & 13 & 15 & 14 & 15 & 6.832 \\
\hline
\end{tabular}




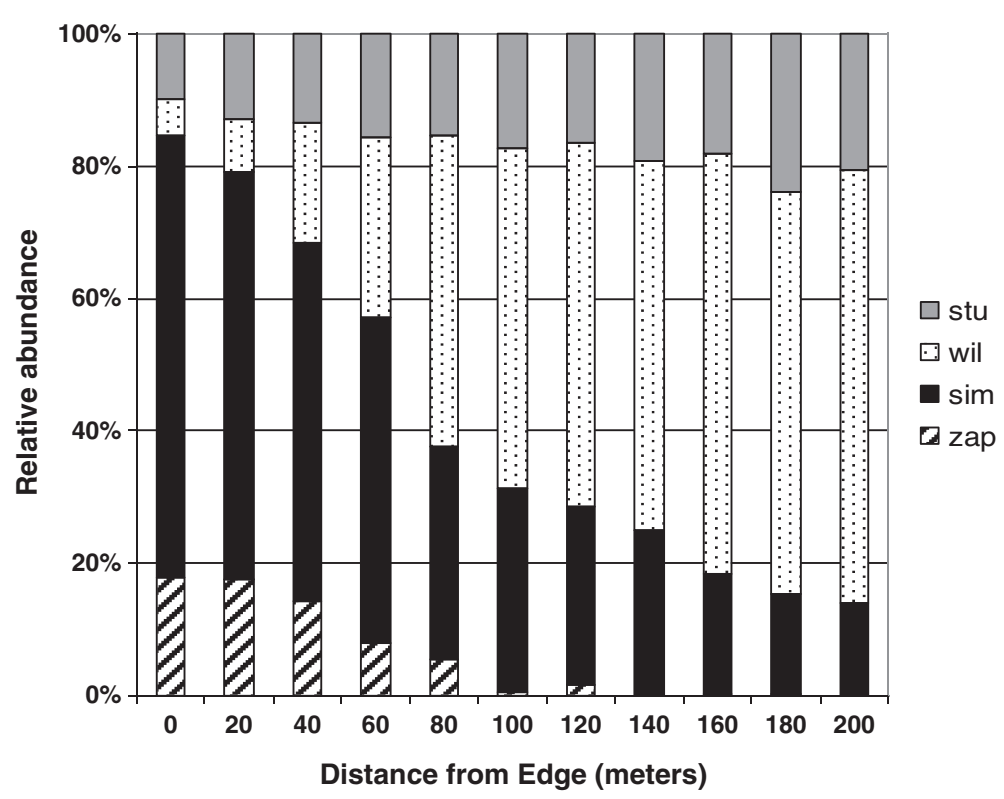

Figure 4 Relative abundance of species collected in the transect (edge-interior of the wood). D. sturtevanti (stu), D. willistoni (wil), D. simulans (sim) and Zaprionus indianus (zap).

Z. indianus is a species that has only recently been introduced in Brazil. On its continent of origin (Africa), this species occupies open savanna (Vilela, 1999). The species' native habitat may partly explain its high abundance only at sampling points that were very near the edge. $Z$. indianus is one of the most successful colonizing species in the genus (Chassagnard and Tsaca, 1993), as it utilizes multiple food sources and displays plasticity with respect to climate (Parkash and Yadav, 1993).
D. simulans is also an exotic species, as are many members of the neotropical drosophilid fauna. This species has been associated with open and/or urban habitats and is resistant to low humidity conditions (Saavedra et al. 1995; Amaral 2004; Ferreira and Tidon, 2005; Torres and Madi-Ravazzi 2006; Schmitz et al. 2007; Mata et al. 2008), which may explain its high dominance at the edge. This species also occurs in the fragment's interior, though this occurs primarily during the dry season (Penariol, 2007).

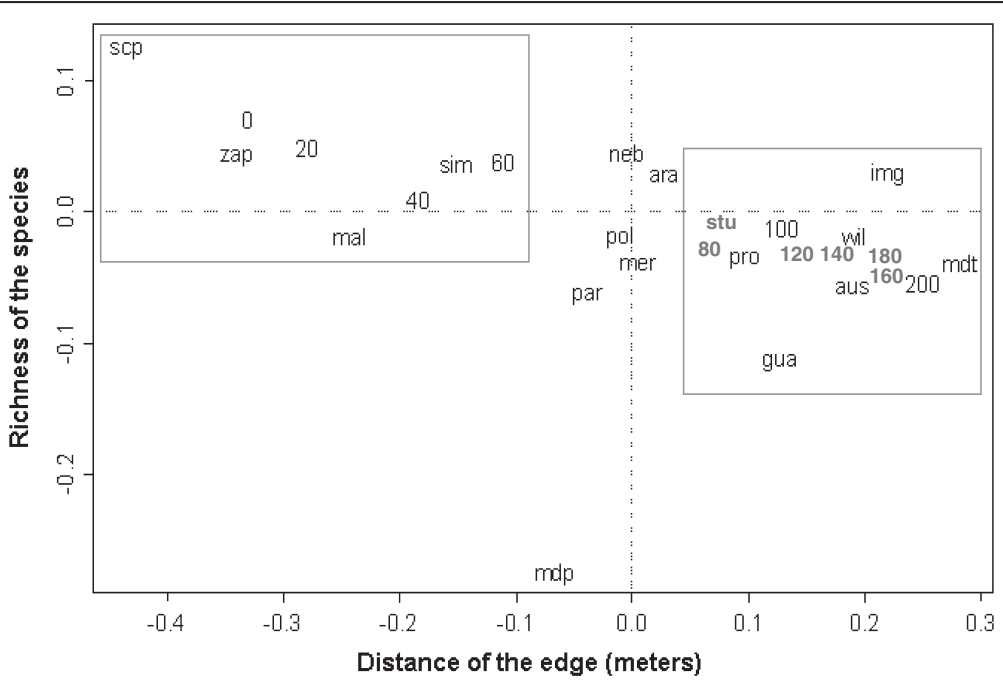

Figure 5 Analysis of dependence (ANADEP), relating the distance of the edge and richness of the species. The points of 0 the 60 correspond to the edge area and of 80 the 200 to the inside of the fragment. S. latifasciaeformis (scp), Z. indianus (zap), D. malerkotliana (mal), D. simulans (sim), D. mediopunctata (mdp), D. paranaensis (par), D. nebulosa (neb), D. polymorpha (pol), D. mercatorum (mer), D. ararama (ara), D. sturtevanti (stu), D. prosaltans (pro), D. guarani (gua), D. willistoni (wil), D. austrosaltans (aus), D. immigrans (img), D. medioatriata (mdt). 
Drosophila willistoni, a native neotropical species, was dominant in the fragment's interior. Data from the literature confirm that this species occurs mainly in forested areas (Saavedra et al. 1995; Amaral 2004; Torres and Madi-Ravazzi 2006). (Ferreira and Tidon 2005) also observed that the species of the family Drosophilidae endemic to the Cerrado biome were unable to invade the city of Brasília (an urban environment associated with varying degrees of habitat stress).

Studies on other organisms in the region of the Ecological Station of Paulo de Faria reinforce the need for monitoring this area to preserve its biodiversity. (Gomes and Noll 2009) compared the diversity and richness of social wasps among three fragments of semideciduous forest located in Paulo de Faria, Pindorama and Neves Paulista. The vegetation in these areas is in different stages of regeneration, and these investigators found that the wasp community of Paulo de Faria showed the lowest species diversity and the greatest abundance. According to these authors, this pattern can be explained by the absence of ecological corridors that limit dispersal.

The results of the present study revealed a distribution gradient in the abundance of drosophilid species along an edge-interior transect in a forest fragment. The study established an edge extent of 60 meters. Moreover, the edge region was characterized by the presence of the invader species $D$. simulans and $Z$. indianus, while the native species $D$. willistoni was associated with the forest interior. These findings indicate that the method presented here is efficient for evaluating edge effects and their extent and can be used in the development of management strategies that aim to preserve forest fragments and detect ecosystem disturbance.

\section{Competing interests}

The authors declare that they have no competing interests.

\section{Authors' contributions}

LP carried out collections and species identification, LM-R and LP performed the analyzes and wrote the manuscript. All authors read and approved the final manuscript.

\section{Acknowledgments}

To Dra. Hermione E. M.de C. Bicudo (Departamento de Biologia, UNESP/ IBILCE) for critically reading earlier versions of the manuscript and for improving the English version. To FAPESP for a fellowship (04/04559-3) given to Leiza Penariol and CAPES for financial support.

Received: 28 December 2012 Accepted: 5 March 2013

Published: 15 March 2013

\section{References}

Acurio A, Rafael V, Dangles O (2010) Biological invasions in the Amazonian tropical rain forest: the case of Drosophilidae (Insecta, Diptera) in Ecuador, South America. Biotropica 42(6):717-723

Amaral O (2004) Biodiversidade e sazonalidade de drosofilídeos na estação ecológica de Paulo de Faria/SP. Tese de Mestrado. Instituto de Biociência, Letras e Ciências Exatas. UNESP, São José do Rio Preto. São Paulo. Brazil
Balanya J, Oller JM et al (2006) Global genetic change tracks global climate warming in Drosophila subobscura. Science 313(5794):1773-1775

Barcha SF, Arid FM (1971) Estudo de evapotranspiração na região norte-ocidental do Estado de São Paulo. Rev Ciência 1:99-122

Bierregaard RO Jr, Lovejoy TE et al (1992) The biological dynamics of tropical rainforest fragments: a prospective comparison of fragments and continuos forest. Bioscience 42:859-866

Chabora PC, Smolin SJ et al (1979) The life of Pseudeucoila sp. a protelian parasite of Drosophila. Ann Entomol Soc Am 72(4):495-499

Chassagnard MT, Tsaca L (1993) Le sous-genre Zaprionus S. Str. Définition de groupes d'éspecies et révision du sous-groupe vittiger (Diptera, Drosophilidae). Ann Soc Entomol Fr 29:173-194

Colwell RK (2004) Estimate S: statistical estimation of species richness and shared species from samples. Version 7. Persistent URL. http://viceroy.eeb.uconn. edu/estimates/

Cordeiro JA, Cordeiro JA (1990) Análise de Dependência: uma Técnica para Estudo de Tabelas Cruzadas. Tese de Livre Docência, UNESP/IBILCE, São José do Rio Preto

de Toni DC, Gottschalk MS et al (2007) Study of the Drosophilidae (Diptera) communities on Atlantic Forest islands of Santa Catarina State, Brazil. Neotrop Entomol 36(3):356-375

Demite P, Feres RJF (2005) Influência de vegetação vizinha na distribuição de ácaros em seringal (Hevea brasiliensis Muell. Arg., Euphorbiacea) em São José do Rio Preto, SP. Neotrol Entomol 34(5):829-836

Fahring L (2003) Effects of habitat fragmentation on biodiversity. Annu Rev Ecol Syst 34:487-515

Ferreira LB, Tidon R (2005) Colonizing potential of Drosophilidae (Insecta, Diptera) in environments with different grades of urbanization. Biodivers Conserv 14:1804-1821

Foote D, Carson HL (2004) Drosophila as monitor of change in hawailian ecosystems. p. 368-372. In: Our Living Resources: A Report to the Nation on the Distribution, Abundance, and Health of U.S. Plants, Animals, and Ecosystems. Senior Science Editor and Project Director: Edward T. LaRoe. U.S. Department of Interior - National Biological Service, Washington, DC, 1995 http://archive.org/stream/ourlivingresourc00unit\#page/368/mode/2up.

Freire-Maia N, Pavan C (1949) Introdução ao estudo de Drosophila. Cultus 1:1-171

Gardner TA, Barlow J et al (2009) Prospects for tropicalforest biodiversity in a human-modified word. Ecol Lett 12:561-582

Gomes B, Noll FB (2009) Diversity of social wasps (Hymenoptera, Vespidae, Polistinae) in three fragments of semideciduous seasonal forest in the northwest of São Paulo State, Brazil. Rev Bras Entomol 53(3):428-431

Gottschalk MS, de Toni DC et al (2007) Changes in Brazilian Drosophilidae (Diptera) assemblages across an urbanisation gradient. Neotrop Entomol 36 (6):848-862. doi:10.1590/S1519-566X2007000600005

Kaneshiro KY (1969) A study of the relationships of Hawaiian Drosophila species basead on external male genitalia. Univ Texas Pub 6918:55-70

Kronka FJN, Matsukuma CK et al (1993) Inventário florestal do estado de São Paulo. Instituto Florestal, São Paulo

Kroodsma RL (1984) Effect of edge on breeding forest bird species. The Wilson Bulletin 96(3):426-436

Laurence WF, Rankin-De-merona JM, Laurence SG (1998) Rain forest fragmentation and the dynamics of Amazonian tree communities. Ecology 79:2032-2040

Laurance WF (2000) Do edge effects occur over large spatial scales? Trends Ecol Evol 15(4):134-135

Laurance WF, Nascimento HEM et al (2007) Habitat fragmentation, variable edge effects, and the landscape-divergence hypothesis. PLoS One 2(10):e1017. http://www.plosone.org/article/info\%3Adoi\%2F10.1371\%2Fjournal. pone. 0001017

Laurance WF, Camargo JLC et al (2011) The fate of Amazonian Forest fragments: a 32-year investigation. Biol Conserv 144:56-67

Martins MB (1989) Invasão de fragmentos florestais por espécies oportunistas de Drosophila (Diptera, Drosophilidae). Acta Amaz 19:265-271

Mata RA, McGeoch M, Tidon R (2008) Drosophillid assemblages as a bioindicator system of human disturbance in the Brazilian Savanna. Biodivers Conserv 17:2899-2916

Mc Geoch MA, Gaston KJ (2000) Edges effects on the prevalence and mortality factors of Phytoyza ilicis (Diptera, Agromyzidae) in a suburban woodland. Ecol Lett 3:23-29

Murcia C (1995) Edge effects in fragmented forests: implications for conservation. TEcol Evol 10:58-62 
Oliveira-Alves A, Peres MCL et al (2005) Estudo das comunidades de aranhas (Aracnida: Aranae) em ambientes de Mata Atlântica no Parque Metropolitano de PituaçuPMP, Salvador, Bahia. Biota Neotrop 5(1a):91-98. doi:10.1590/S167606032005000200008

Oliveira-Filho AT, Carvalho DA et al (2004) Variações estruturais do compartimento arbóreo de uma floresta semidecídua alto-montanha na chapada dos Perdizes, Carrancas, MG. Ver. Brasil. Bot 27(2):291-309

Parkash R, Yadav JP (1993) Geographical clinal variation at 7 esterase-coding loci in Indian populations of Zaprionus indianus. Hereditas 119:161-170

Parsons PA (1991) Biodiversity conservation under global climatic change: the insect Drosophila as a biological indicator? Global Ecol Biogeogr 1(3):77-83

Penariol L (2007) Assembléia de drosofilídeos na borda e no interior de um fragmento de floresta estacional no noroeste do Estado de São Paulo. $91 \mathrm{f}$. Tese (Mestrado). Instituto de Biociência, Letras e Ciências Exatas, São José do Rio Preto, São Paulo, Brazil

Penariol L, Bicudo HEMC, Madi-Ravazzi L (2008) On the use of open or closed traps in the capture of drosophilids. Biota Neotrop 8(2):47-51. doi:10.1590/ S1676-06032008000200004

Peres CA, Gardner TA et al (2010) Biodiversity conservation in human-modified Amazonian forest landscapes. Biol Conserv 143:2314-2327

Prince GJ (1976) Laboratory biology of Phaenocarpapersimilis l'app (Braronida: Alysienae), a parasitoid of Drosophila. Aust J Zool 24(2):249-264

Rossa-Feres DC, Jim J (2001) Similaridade do sítio de vocalização em uma comunidade de anfíbios Anuros na região noroeste do Estado de São Paulo. Rev Bras Zool 18(2):439-454

Saavedra CCR, Callegari-Jacques SM et al (1995) A descriptive and analytical study of four neotropical drosophilids communities. Zool System Evol Research J 33:62-74

Schmitz HJ, Valente VLS, Hofmann PRP (2007) Taxonomic survey of Drosophilidae (Diptera) from mangrove forest of Santa Catarina Island, southern Brazil. Neotrop Entomol 53:53-64

Sene FM, Val FC et al (1980) Preliminary data on the geographical distribuition of Drosophila species within morphoclimatic domains of Brazil. Pap Avulsos de Zool 33(22):315-326

SMA/IF Secretaria do Meio Ambiente/Instituto Florestal (2005) Inventário Florestal da Vegetação Natural do Estado de São Paulo. Imprensa Oficial do Estado de São Paulo, São Paulo

Tidon-Sklorz R, Sene FM (1992) Vertical and temporal distribuition of Drosophila (Diptera, Drosophilidae) species in a wooded area in the state of São Paulo, Brazil. Rev Bras Biol 52:311-317

Torres FR, Madi-Ravazzi L (2006) Seasonal variation in natural populations of Drosophila spp (Diptera) in two woodlands in the State of São Paulo, Brazil. Iheringia Ser Zool 96(4):437-444

Vilela CR (1983) A revision of the Drosophila repleta species group (Diptera, Drosophilidae). Rev Bras Ent 27:1-114

Vilela CR (1999) Is Zaprionus indianus Gupta, 1970 (Díptera, Drosophilidae) currently colonizing the Neotropical region? Dros Inf Serv 82:37-39

doi:10.1186/2193-1801-2-114

Cite this article as: Penariol and Madi-Ravazzi: Edge-interior differences

in the species richness and abundance of drosophilids in a

semideciduous forest fragment. SpringerPlus 2013 2:114

\section{Submit your manuscript to a SpringerOpen ${ }^{\circ}$ journal and benefit from:}

- Convenient online submission

- Rigorous peer review

- Immediate publication on acceptance

- Open access: articles freely available online

- High visibility within the field

- Retaining the copyright to your article

Submit your next manuscript at $>$ springeropen.com 